\title{
Urgences
}

\section{Sans noms, sans culottes et amours d'autoroute}

\section{Virginia Chose}

Numéro 20, mai 1988

Appellation contrôlée

URI : https://id.erudit.org/iderudit/025463ar

DOI : https://doi.org/10.7202/025463ar

Aller au sommaire du numéro

Éditeur(s)

Urgences

ISSN

0226-9554 (imprimé)

1927-3924 (numérique)

Découvrir la revue

Citer ce document

Chose, V. (1988). Sans noms, sans culottes et amours d'autoroute. Urgences, (20), 13-13. https://doi.org/10.7202/025463ar d'utilisation que vous pouvez consulter en ligne.

https://apropos.erudit.org/fr/usagers/politique-dutilisation/ 


\section{VIRGINIA CHOSE \\ Sans noms, sans culottes et amours d'autoroute}

1- Pas de nom, pas d'héritage - Sans droit d'auteur! L'anonymat tranche à coup sûr l'obligation de rendre des comptes. Sans nom, image grotesque, celle du sans visage comme on dit parfois des sans culottes. Cependant le plaisir de la fete doit au camouflage et au masque l'accomplissement du rire, de la peur: double revanche de la modestie. Le nom est sérieux, l'anonyme est pitre. Mais quelle réjouissance à pratiquer l'injure et l'insolence sans la scène étroite de l'office des pourvoyeurs de noms.

2- Le nom est-ce bien ce tout ou plutôt l'anonyme? Fétiche, cette désignation a quelque chose d'obscène tellement elle se gonfle pour soulever le bas du texte. Le nom brille. Mon prochain plaisir: lire des textes sans auteurs!

3- Quel est votre nom? Vous n'avez pas à le savoir! Usurpation. Bizarre qu'il faille un nom pour y être personne en particulier. Je sais pourtant ce nom que je porte parfois comme un simulacre. Mon nom suffit alors à me faire taire. Oh! Mon nom, je le graphie par vengeance du chiffre ou de la génétique. J'appartiens au catalogue du propice... Allez-y voir.

4- Ce nom est personne. Là, mon corps résonne avec la gravité qui vient me chercher pour circuler à l'aise quand «parler, ce n'est pas remuer la langue».

5- L'anonymat, c'est l'auteur avalé: la défection du visage. Mais la trace certaine de ce qui touche sans avoir à demeurer au bord du miroir de la re-connaissance. «Totus homo - et mulier - fit excrementum». Sans nom. Dès que Narcisse touchait, il ne se voyait plus.

6- Je file. Depuis que le jour s'est levé, je fabrique le personnage qui me suit, maintenant les phares éteints. J'invente à partir de rares indices les scénarios des amours d'autoroute. Anonyme, la ligne blanche défile. Animalité du désir. Le nom, quel vice. J'accélère. 